\title{
Continued suspense: EC-Hormones and WTO disciplines on discrimination and domestic regulation Appellate Body Reports: Canada/United States - Continued Suspension of Obligations in the EC - Hormones Dispute, WT/DS320/AB/R,WT/DS321/AB/R, adopted 14 November 2008
}

\author{
BERNARD HOEKMAN * \\ World Bank and CEPR \\ JOEL TRACHTMAN \\ Tufts University ${ }^{1}$
}

\begin{abstract}
Based on the reasoning of the Appellate Body in Canada/United States - Continued Suspension of Obligations in the EC-Hormones Dispute ('Continued Suspension'), this paper analyzes the distinction between the national-treatment obligation under Article III of GATT and the requirement under the Agreement on Sanitary and Phytosanitary (SPS) Measures that such measures be based on a risk assessment that takes into account available scientific evidence. The Appellate Body's reasoning makes clear that the primary purpose of the SPS Agreement is to discipline discriminatory regulation, and not the level of protection. We argue that the case clarifies that de facto protection (market segmentation) created by an SPS measure must be motivated by demonstrating that the measure is addressing a market failure, as reflected in the existence of some scientific basis for a health or safety concern. The scientific-basis requirement is a means for determining the intent of an SPS measure. While this is a factor that is ostensibly not relevant in GATT national-treatment cases, the need for scientific justification is not a move away from a concern with preventing illegitimate discrimination against imported products.
\end{abstract}

\footnotetext{
*Email: bhoekman@worldbank.org

1 This paper was prepared for The American Law Institute Principles of World Trade Law project. We are grateful for comments by participants in that project, and especially Henrik Horn and Joost Pauwelyn. The views expressed are personal and should not be attributed to the World Bank.
} 


\section{Introduction}

In the case of Canada/United States - Continued Suspension of Obligations in the EC-Hormones Dispute (Continued Suspension), the European Communities (EC) challenged continued suspension of WTO concessions by the US and Canada. The US and Canada justified the suspension of concessions on the basis of the EC's alleged violation of the Agreement on Sanitary and Phytosanitary Measures (the SPS Agreement), continuing from an earlier case in which a WTO disputesettlement proceeding concluded that the EC violated its obligations under the SPS Agreement, and in which the US and Canada were authorized to suspend concessions.

While this decision addresses important adjectival issues, the main substantive issue in this case is the question of the scope of disciplines on domestic regulation for sanitary and phytosanitary purposes. The SPS Agreement intensifies the disciplines on domestic regulation compared to the General Agreement on Tariffs and Trade (GATT) alone. The GATT only requires that domestic regulation of products be applied on a non-discriminatory basis, both in the national-treatment and in the most-favored-nation (MFN) sense. The SPS Agreement goes beyond this by specifying additional conditions that must be satisfied by SPS product regulations. Continued Suspension clarified what those conditions are and how they should be applied and interpreted in practice.

This paper seeks to better understand the precise parameters and nature of the difference between the pre-1995 GATT tests for discrimination and the post1995, 'post-discriminatory', additional disciplines that are embodied in the SPS Agreement. We will argue that the approach taken by the Appellate Body is consistent with a view of SPS regulation as a mechanism that is (and should be) focused on addressing consumption externalities in the importing country, and that the specific criteria that are imposed to determine the WTO legitimacy of SPS measures are an effort to ensure that regulation is indeed directed towards addressing a non-pecuniary externality as opposed to an effort to improve the terms of trade. As is the case in other areas of WTO law affecting domestic 'behind the border' policy instruments, the disciplines are relatively weak in the sense that they allow for substantial discretion regarding the specific features of the product regulation that may be imposed by an importing government: what the SPS Agreement does is to impose (weak) conditions on governments aimed at ensuring that the aim of the regulation is to address a true consumption externality through the requirement that any regulation, whatever the level chosen, has an objective (scientific) basis.

Thus, our interpretation of the Appellate Body's reasoning is that the primary purpose of the SPS Agreement is to discipline discriminatory regulation, and not to address instances of inefficient non-discriminatory product regulation, including inefficient choices of excessive levels of protection. Based on our reasoning, it is not impossible to infer that the SPS Agreement is designed to discipline regulation that 
is simply ignorant, failing to achieve its purported goal without discrimination. However, we argue that the distinction between discrimination analysis and rationality analysis is not as great as it might at first appear. The SPS Agreement is aimed at overcoming specific difficulties that arise in applying the general GATT non-discrimination rules to this area of regulation as it affects imported products.

This paper is organized as follows. Section 1 briefly reviews basic analytical insights and considerations that arise in connection with product regulation in the area of food, plant, and animal health and safety. In Section 2 we describe the facts and main holdings of Continued Suspension. In Section 3, we evaluate the distinction between the national-treatment obligation under Article III of GATT, and the requirement under the SPS Agreement that SPS measures be based on a risk assessment that takes into account available scientific evidence (Art. 5.1), as modified by Article 5.7 in situations where such evidence is insufficient. We evaluate this distinction from a doctrinal and jurisprudential standpoint, seeking to compare the distinct elements of each of these two disciplines on domestic regulation. In Section 4 we discuss the relationship between discrimination and 'post-discrimination' disciplines and a number of 'gaps' in the GATT discrimination rules that help to understand the 'additionality' of the SPS Agreement as it has been interpreted by the Appellate Body. Section 5 concludes.

\section{Conceptual considerations}

Key provisions in the SPS Agreement provide that Members must ensure that any SPS measure be applied only to the extent necessary to protect human, animal, or plant life or health, that SPS measures must be based on scientific principles (Art. 2.2), and that a reflection of this requirement is that governments must base any SPS measure on an assessment of the risks to human, animal, or plant life or health, taking into account risk-assessment techniques developed by relevant international organizations (Art. 5.1). The risk assessment must identify the diseases, pests, etc. a Member wants to prevent in its territory, identify the potential biological and economic consequences associated with such diseases, and evaluate the likelihood of entry, establishment, or spread of these diseases (Art. 5.3). In the assessment of risks, available scientific evidence must be considered, as well as relevant processes and production methods; inspection, sampling, and testing methods; and the prevalence of specific diseases or pests and environmental conditions (Art. 5.2). In cases where relevant scientific evidence is insufficient, a Member may provisionally adopt SPS measures on the basis of available pertinent information, including that from the relevant international organizations as well as from SPS measures applied by other Members (Art. 5.7). If such provisional measures are imposed, Members must seek to obtain the additional information necessary for a more objective assessment of risk and review the SPS measure accordingly within a reasonable period of time. 
From a social-welfare perspective, technical product regulations - of which SPS measures are a specific subcategory - are measures that can be justified as instruments to deal with specific market failures. Possible rationales for product regulation include imperfect information, uncertainty, market power, and other sources of externalities in production or consumption. Although product regulation can improve welfare if it succeeds in internalizing spillovers at acceptable transaction costs (i.e., improves allocative efficiency), this need not be the purpose or outcome. The intervention may also allow incumbent firms in an industry to exploit market power. Product standards are one of the possible instruments through which a firm or industry can induce government to raise rivals' costs. Given compliance costs, regulation may reduce the contestability of a market, because potential entrants find it less attractive to compete or to enter. The greater are the barriers to entry created by the regulation for foreign firms (the fixed compliance costs), the greater will be the profit-enhancing (shifting) effect of the product-regulation measure for the domestic firms or industry, all other things being equal. Thus, regulation can be employed strategically to shift rents.

In general, if product regulations differ across countries, this will segment markets, even if each country applies identical norms to domestic and foreign goods (i.e. the national-treatment rule is satisfied). Prices for similar goods of uniform quality will then not be equal across countries, as the different standards inhibit arbitrage. Thus, non-discriminatory product regulation can have effects on trade - and afford de facto protection to a domestic industry.

There are many types of market failures that can justify government intervention in the form of product regulation. In the case of SPS measures, the primary rationales are either imperfect/asymmetric information problems or negative externalities. Consumption externalities may arise as a result of certain types of production processes giving rise to product characteristics that cannot be readily observed by buyers and that may be harmful to animal, plant, or human health and safety, especially in the medium or longer term. To a significant degree, consumer food products are credence goods, especially when it comes to the extent to which non-noticeable factors associated with the production process - e.g. hormone residues - have potential long-term consequences for health.

The negative externality may arise as a result of the consumption of imported foreign products that embody or carry pests or diseases that may harm consumers or have seriously detrimental effects on local production of crops, livestock, or biodiversity assets. In the case of information problems, consumers may not have the means to determine whether producers use inputs that result in harmful substances being embodied in a product that will generate detrimental consequences over time, not just for the consumer directly, but for society more broadly. For example, milk used to be a product that killed thousands in the late nineteenth and early twentieth centuries - product 
regulation helped to improve quality greatly over time (Olmstead and Rhode, 2009). ${ }^{2}$

The SPS Agreement applies to a limited set of measures that are identified by their purpose. The market-failure case for SPS regulation distinguishes this area from the more general taxation and regulation that is covered by the GATT national-treatment principle. In the case of general taxation and regulation, the objective of intervention often will not be to address the types of externalities that (should!) motivate SPS regulation. As extensively analyzed in the literature on trade agreements, although some subset of non-SPS-related domestic taxation and regulation will be aimed at internalization of specific externalities (i.e. addressing market failures), the reason trade agreements include disciplines on the use of domestic taxes and regulation is that these instruments can be used as substitutes for trade barriers to influence the terms of trade. A rationale for the nationaltreatment rule for domestic taxes and regulation is that it is a necessary condition for tariff commitments to be meaningful.

In the SPS area, the presumption is that government intervention is needed to protect consumers and producers from product characteristics that can be harmful at either the individual or social/industry level. The problem from a trade perspective is that SPS regulation may inadvertently have negative effects on foreign producers or may be deliberately abused for protectionist purposes. Moreover, the standard may not be set at the level appropriate to internalize the local consumption externality.

The negative trade effect of an efficient non-discriminatory product regulation - i.e. one that addresses the information problems or consumption externality that give rise to market failure - on foreign producers is not something that should be dealt with through a change in the regulation that is applied, as (by construction - given that the regulation is efficient) that would result in the local externality no longer being fully offset. If the problem is a local consumption externality or market failure and the product regulation deals with that in an efficient manner, the importing country has achieved the first-best solution.

However, if the regulation is not efficient, either because standards are set in a way that increases domestic profits (by reducing foreign competition) by less than the losses incurred by consumers (either directly in pecuniary terms or indirectly in terms of the relevant externalities continuing to persist), or because of imperfect information, foreign interests may help identify a measure that reduces costs of compliance (differential effects) and/or comes closer to dealing with the market failure. In these cases, objective analysis and information is a key input into informed debate and deliberation on the source and magnitude of the market failure, and on whether a specific SPS regulation serves to address the problem in an

2 Alan Olmstead and Paul Rhode (2009), 'The battles against animal diseases: science, policy, and the origins of economic regulation in the United States', http://ele.arizona.edu/papers/ELErhode2-6-09.pdf. 
effective and efficient manner. This will often be a public good, affected by the classic collective-action constraints identified by Mancur Olson. ${ }^{3}$

In general, given differences in circumstances, social preferences, and risk attitudes across countries, product regulation will need to differ. It is of course in practice very difficult to identify what constitutes an efficient regulation as there is much uncertainty regarding the health effects of specific substances, both ex ante and ex post. This suggests that international cooperation can be beneficial by increasing information and scrutiny of the effects, efficacy, and equivalence of specific product regulations. ${ }^{4}$ The various provisions in the SPS Agreement that call for adoption of international SPS norms where these exist or are developed and the process of notification and discussion in the SPS Committee are important elements of such cooperation that have already been put in place. However, absent agreement that countries will accept products that meet certain minimum standards, the fact that governments are free to adopt idiosyncratic norms will always bring with it differential trade effects, as firms will confront differences in market-specific costs of contesting different foreign markets. Absent a willingness to agree to abide by international norms or to accept mutual recognition (both of which may result in inefficiency at the local level), the challenge confronting WTO members is to ensure that national norms indeed are directed towards dealing with national consumption externalities, while seeking to minimize as much as possible the scope for protectionist abuse of SPS norms.

As we argue below, the SPS Agreement and the way its provisions have been interpreted by the Appellate Body are an effort to address this challenge in a way that gives governments great leeway regarding the substance and thus the level of the market segmenting effects created by specific SPS norms. As a result, the effective disciplines that are imposed through the requirement that SPS measures be justified on the basis of scientific principles (risk assessment, etc.) are in practice rather weak. The implication is that the SPS Agreement does not take the WTO very far towards imposing 'post-discrimination' disciplines on domestic regulation.

\section{Continued Suspension}

\section{Facts}

In the original 1998 EC-Hormones case, ${ }^{\mathbf{5}}$ the European Communities' (EC) import ban on meat and meat products from cattle treated with six

3 Mancur Olson (1965), The Logic of Collective Action: Public Goods and the Theory of Groups, Cambridge, MA: Harvard University Press.

4 See Robert Howse (2000), 'Democracy, Science and Free Trade: Risk Regulation on Trial at the World Trade Organization', 98 Michigan Law Review 2329.

5 Appellate Body Report, EC - Measures Concerning Meat and Meat Products (EC-Hormones), WT/ DS26/AB/R, WT/DS48/AB/R, adopted 13 February 1998, DSR 1998:I, 135. 
hormones - oestradiol-17 $\beta$, testosterone, progesterone, trenbolone acetate, zeranol, and MGA - was found to violate Article 5.1 of the SPS Agreement. The Appellate Body (AB) in the 1998 decision found that the EC's scientific studies were not 'sufficiently specific to the case at hand', because they did 'not address the particular kind of risk ... at stake - the carcinogenic or genotoxic potential of the residues of those hormones found in meat derived from cattle to which the hormones had been administered for growth promotion purposes'. ${ }^{6}$ Therefore, the $\mathrm{AB}$ concluded that 'no risk assessment that reasonably support[ed] or warrant[ed] the import prohibition embodied in the Directives was furnished to the Panel'. ${ }^{7}$

Following the adoption of the AB report in the 1998 EC-Hormones case, the European Commission funded 17 scientific studies regarding the effects of hormone residues in meat on human health. The EU Scientific Committee on Veterinary Measures relating to Public Health (SCVPH) issued an opinion regarding the human health effects in 1999, which was revised in 2000 and 2002. The EC argued that the 1999, 2000, and 2002 SCVPH opinions, supported by these 17 scientific studies conducted between 1998 and 2001, constituted the risk assessment upon which the ban under Directive 2003/74/EC on meat treated with these hormones was based. Directive 2003/74/EC maintained the permanent prohibition on the importation of meat and meat products from animals treated with oestradiol- $17 \beta$ for growth-promotion purposes originally contained in Directive 96/22/EC. In relation to the five other hormones - testosterone, progesterone, trenbolone acetate, zeranol, and MGA - Directive 2003/74/EC imposed the prohibition on a provisional basis. ${ }^{8}$

Despite the EC argument that this work (the SCVPH opinions, based on the 17 scientific studies) constituted an appropriate risk assessment upon which its ban was based, Canada and the US continued to suspend concessions in relation to the earlier finding of violation. The EC argued that the measure found to violate WTO law had been removed, requiring the termination of suspension of concessions under Article 22.8 of the Dispute Settlement Understanding by the US and Canada. The EC argued that the continuation of suspension of concessions violated Article 23.1 of the Dispute Settlement Understanding, which requires Members seeking to redress perceived violations of obligations or other nullification or impairment of benefits under the WTO to have recourse to, and abide by, the rules and procedures of the WTO's dispute-settlement mechanism.

The Panel considered that it was required to address the consistency of Directive 2003/74/EC with Articles 5.1 and 5.7 of the Agreement in order to determine whether the US and Canada's continued suspension of concessions

6 EC-Hormones, para. 200.

7 EC-Hormones, para. 208.

8 Appellate Body Report, US-Continued Suspension, para. 267. 
was or was not in violation of Article 23.1 of the Dispute Settlement Understanding.

\section{Main salient holdings}

SPS 5.1

The Panel determined first that Directive 2003/74/EC constituted an SPS measure under paragraph 1 of Annex A to the SPS Agreement, and in particular, item (b). ${ }^{9}$ This threshold question determines the applicability of the SPS Agreement, as opposed to the TBT Agreement, or perhaps only the GATT 1994. This determination was not appealed.

The EC appealed the Panel's finding that the permanent EC ban on meat and meat products from cattle treated with oestradiol-17 $\beta$ for growth-promotion purposes provided for in Directive 2003/74/EC violates Article 5.1 of the SPS Agreement.

The EC argued that the Directive was 'based upon' a risk assessment as required by Article 5.1, which risk assessment was comprised of the 1999, 2000, and 2002 SCVPH opinions (the 'SCVPH Opinions'), which in turn were based on the 17 studies mentioned above.

The AB began its analysis under Article 5.1 by explaining the disciplines imposed by the SPS Agreement in this context:

The SPS Agreement recognizes the right of WTO Members to take measures necessary to protect human, animal or plant life or health. The right to take a protective measure must be exercised consistently with a series of obligations that are set forth in that Agreement, and that seek to ensure that such measures are properly justified..$^{10}$

As explained in more detail below, the obligations set forth in the SPS Agreement seem intended to go beyond those of non-discrimination set forth in the GATT. The AB noted that Member States are free to set their 'appropriate level of protection' to be effected through their SPS measures. While the Codex Alimentarius Commission - the relevant international standards-setting body, a joint office of the Food and Agricultural Organization (FAO) and the World Health Organization (WHO) - has adopted an international standard for oestradiol-17 $\beta$, based on evaluations carried out by the Joint FAO/WHO Expert Committee on Food Additives (JECFA), the EC had decided on a higher level of protection, involving zero avoidable risk. ${ }^{11}$ It was in order to achieve this higher level of protection that the EC adopted Directive 2003/74/EC.

The AB cited the original EC-Hormones decision for the proposition that Article 5.1 is a 'specific application of the basic obligations contained in Article 2.2

9 Panel Report, US-Continued Suspension, para. 7.434.

10 Appellate Body Report, US-Continued Suspension, para. 522.

11 Panel Report, US-Continued Suspension, para. 7.607. 
of the SPS Agreement'. Article 5.1 must constantly be read together with Article 2.2. Article 2.2 provides as follows:

Members shall ensure that any sanitary or phytosanitary measure is applied only to the extent necessary to protect human, animal or plant life or health, is based on scientific principles and is not maintained without sufficient scientific evidence, except as provided for in paragraph 7 of Article 5.

The risk assessment called for by Article 5.1 is a process by which to establish the scientific basis for the relevant SPS measure. When Article 5.1 requires that SPS measures be 'based on' the relevant risk assessment, it means that there must be a rational relationship between the SPS measure and the risk assessment. ${ }^{12}$

The Panel applied a four-prong test for determining whether the SCVPH Opinions constituted a valid risk assessment under Article 5.1: (i) whether the SCVPH Opinions took into account risk-assessment techniques of the relevant international organizations; (ii) whether they took into account the factors listed in Article 5.2, including available scientific evidence; (iii) whether they satisfied the definition of 'risk assessment' contained in Annex A, paragraph 4, of the SPS Agreement, including evaluation of the likelihood and consequences of entry of a product; and (iv) whether the conclusions of the SCVPH Opinions are supported by the scientific evidence evaluated.

The US had alleged that the SCVPH Opinions had failed to take into account available scientific evidence, and relevant inspection, sampling, and testing methods, as required under Article 5.2. However, the Panel found that the SCVPH Opinions had specifically taken into account the scientific evidence cited by the US, and that the EC had taken into account all relevant inspection, sampling, and testing methods. ${ }^{13}$

The Panel found that the EC had 'not satisfied the requirements of the definition of a risk assessment contained in Annex A(4) because it ha[d] not evaluated specifically the possibility that these adverse effects come into being, originate, or result from the consumption of meat or meat products which contain veterinary residues of oestradiol- $17 \beta$ as a result of the cattle being treated with the hormone for growth promotion purposes'. ${ }^{14}$ Although the EC had shown the general association between excess hormones and neurobiological, developmental, reproductive, and immunological effects, as well as immunotoxicity, genotoxicity, and

12 Appellate Body Report, US-Continued Suspension, para. 528, citing Appellate Body Report, EC-Hormones, para. 193.

13 Panel Report, US-Continued Suspension, paras. 7.483 and 7.484.

14 Paragraph 4 of Annex A of the SPS Agreement provides as follows: 4. Risk assessment- 'The evaluation of the likelihood of entry, establishment or spread of a pest or disease within the territory of an importing Member according to the sanitary or phytosanitary measures which might be applied, and of the associated potential biological and economic consequences; or the evaluation of the potential for adverse effects on human or animal health arising from the presence of additives, contaminants, toxins or disease-causing organisms in food, beverages or feedstuffs.' 
carcinogenicity, it failed to show the specific association between these particular residues and these adverse effects. ${ }^{15}$ The $\mathrm{AB}$ agreed with the Panel:

The definition of a risk assessment in paragraph 4 of Annex A, as interpreted by the Appellate Body, required the European Communities to conduct a risk assessment that addresses the specific risk at issue. The particular risk being evaluated by the European Communities in this case was the potential for neurobiological, developmental, reproductive, and immunological effects, as well as immunotoxic, genotoxic and carcinogenic effects from the residues of oestradiol- $17 \beta$ found in meat derived from cattle to which this hormone was administered for growth-promoting purposes. Although the European Communities is correct in arguing that it was not required to demonstrate that these adverse health effects would actually arise, it was nevertheless required to demonstrate that these adverse effects could arise from the presence of residues of oestradiol- $17 \beta$ in meat from treated cattle. ${ }^{16}$

Of course, all scientific work involves extrapolation. For example, a scientific risk assessment might extrapolate from the risks of a particular formulation or application of oestradiol- $17 \beta$ to the risks of a slightly varying formulation or application. So, when the $\mathrm{AB}$ calls for a more specific risk assessment, even though it does not require that the contribution to risk be isolated, it is making a judgment regarding the permissible extent of extrapolation. It is interpreting the SPS Agreement to require some relevant scientific basis, rather than a relatively broad extrapolation.

The Panel also went on to find that the EC had failed to satisfy the fourth requirement of the definition of risk assessment: the requirement that the scientific evidence support the conclusions. Here, importantly for the subsequent analysis in this paper, the Panel found that the scientific evidence referred to in the SCVPH Opinions did not support the conclusion that the genotoxicity of oestradiol- $17 \beta$ had been demonstrated and that residues of oestradiol-17 $\beta$ in meat lead to increased risk of cancer or adverse immunological and developmental effects. ${ }^{17}$

At the core of the EC appeal was the argument that the Panel had substituted its own judgment for that of the relevant WTO member. ${ }^{18}$ The AB clarified that 'the review power of a panel is not to determine whether the risk assessment undertaken by a WTO Member is correct, but rather to determine whether that risk assessment is supported by coherent reasoning and respectable scientific evidence and is, in this sense, objectively justifiable'. ${ }^{19}$ That is, the disciplines that are imposed are more of a procedural nature. This approach is comparable to the AB's approach to objective indicia of intent in Japan-Alcoholic Beverages, discussed below.

15 Panel Report, US-Continued Suspension, para. 7.537.

16 Appellate Body Report, US-Continued Suspension, para. 559 (citation omitted).

17 Panel Report, US-Continued Suspension, para. 7.572.

18 European Communities' Appellant's Submission, para. 248.

19 Appellate Body Report, US-Continued Suspension, para. 590. 
A panel must also determine whether the results of the risk assessment 'sufficiently warrant' the SPS measure. ${ }^{20}$ In first looking at expert opinion, and then examining whether the EC risk assessment agreed with this opinion, the Panel gave too little deference to the member's retained autonomy to engage in its own risk assessments. ${ }^{21}$ Therefore, the $\mathrm{AB}$ determined that 'the Panel failed to conduct an objective assessment of the facts of the case, as required by Article 11 of the DSU, in determining whether the European Communities' risk assessment satisfied the requirements of Article 5.1 and Annex A of the SPS Agreement., ${ }^{22}$

Accordingly, the AB reversed the Panel's finding that the EC failed to satisfy the requirements of Article 5.1 and Annex A, paragraph 4, of the SPS Agreement. The $\mathrm{AB}$ declined to complete the analysis, in light of the 'numerous flaws' in the Panel's analysis. $^{23}$

The AB also reversed the Panel's exclusion from consideration of the risks of abuse or misuse of hormones. ${ }^{24}$ Although the Panel found that it need not consider risks of abuse or misuse where there was no evidence of a specific link between use of oestradiol- $17 \beta$ in meat and the adverse effects cited, the $\mathrm{AB}$ found some evidence in the record that abuse or misuse could be relevant to the determination of this specific link. ${ }^{25}$

SPS Article 5.7

Where there is sufficient scientific evidence, Article 5.1 must be satisfied. Where there is not, Article 5.7 provides that:

In cases where relevant scientific evidence is insufficient, a Member may provisionally adopt sanitary or phytosanitary measures on the basis of available pertinent information, including that from the relevant international organizations as well as from sanitary or phytosanitary measures applied by other Members. In such circumstances, Members shall seek to obtain the additional information necessary for a more objective assessment of risk and review the sanitary or phytosanitary measure accordingly within a reasonable period of time.

There is thus a continuum of application of Articles 5.1 and 5.7, determining the alternative necessary to be met in connection with SPS measures. ${ }^{26}$ The application of Article 5.1 or 5.7 is based on the determination of whether there is sufficient evidence necessary to support a risk assessment under Article 5.1. ${ }^{27}$

The EC argued before the Panel that the SCVPH Opinions and supporting studies provided the 'available pertinent information' within the meaning of

20 Ibid., para. 591.

21 Ibid., paras. 598-602.

22 Ibid., para. 616.

23 Ibid., para. 620.

24 Ibid., para. 545.

25 Ibid., paras. 547-555.

26 Ibid., para. 674.

27 Ibid., para. 702, citing Appellate Body Report, Japan-Apples, para. 179. 
Article 5.7 on the basis of which the provisional ban on the five hormones had been enacted. ${ }^{28}$ The Panel found that the EC's provisional ban under Directive 2003/74/ EC failed to comply with Article 5.7 of the SPS Agreement because the relevant scientific evidence was not insufficient within the meaning of that provision. ${ }^{29}$

The AB disagreed with the Panel's finding that 'the determination of whether scientific evidence is sufficient to assess the existence and magnitude of a risk must be disconnected from the intended level of protection'. The fact that there was patently sufficient scientific evidence for the establishment of an international standard is not determinative. Rather, 'the fact that the WTO Member has chosen to set a higher level of protection may require it to perform certain research as part of its risk assessment that is different from the parameters considered and the research carried out in the risk assessment underlying the international standard'. ${ }^{30}$

One question that arose in this case has to do with the dynamic nature of science, by virtue of which a body of evidence deemed sufficient at a particular moment to support an international standard might later become insufficient. Here, the $\mathrm{AB}$ rejected the Panel's finding that, where international standards exist, 'there must be a critical mass of new evidence and/or information that calls into question the fundamental precepts of previous knowledge and evidence so as to make relevant, previously sufficient, evidence now insufficient' within the meaning of Article 5.7.31 Rather, 'it suffices that new scientific developments call into question whether the body of scientific evidence still permits of a sufficiently objective assessment of risk'. ${ }^{32}$

In light of the above, the AB reversed the Panel's finding that 'it has not been demonstrated that relevant scientific evidence was insufficient, within the meaning of Article 5.7 of the SPS Agreement, in relation to any of the five hormones with respect to which the European Communities applies a provisional ban ${ }^{33}$ It did not consider it possible to complete the analysis.

\section{WTO Discipline of Domestic Regulation: Comparing the GATT III/XX Complex to the SPS 2.2/5.1/5.7 Complex}

One of the most contentious issues in WTO law is the discipline applied to domestic prudential regulation. ${ }^{34}$ This discipline was substantially changed, and is

28 Panel Report, US-Continued Suspension, para. 7.581. The five hormones were progesterone, testosterone, zeranol, trenbolone acetate, and MGA.

29 Appellate Body Report, US-Continued Suspension, para. 621.

30 Ibid., paras. 685-688.

31 Ibid., para. 712, quoting Panel Report, US-Continued Suspension, para. 7.648.

32 Ibid., para. 725.

33 Ibid., para. 734, quoting Panel Report, US-Continued Suspension, para. 7.835.

34 By 'prudential regulation', we mean regulation whose primary purpose is consumer protection, environmental protection, or other broad societal protection, but not regulation designed to engage in economic management, such as subsidies, protection from imports, monetary policy, etc. 
commonly understood to have been substantially extended in 1995 with the advent of the SPS Agreement and the revised TBT Agreement. Hudec described the change as a move from the pre-1995 test for discrimination to a 'postdiscriminatory ${ }^{\mathbf{3 5}}$ discipline on domestic regulation as follows:

Traditionally, trade agreements have focused on limiting or eliminating discrimination against foreign trade by disciplining governmental measures that impose competitive disadvantages on foreign goods vis-à-vis domestic goods with which they compete. In the recent Uruguay Round trade agreements, however, it appears that the draftsmen of two key agreements added another goal, one that can be described as the prevention of unjustified regulation per se, whether or not such a regulation creates a competitive disadvantage for foreign goods vis-à-vis domestic goods. Thus, for example, a food safety measure that is not based on scientific principles would be a violation of Article 2 of the Agreement on the Application of [SPS] Measures, whether or not it discriminates against foreign goods. While other rules of the SPS Agreement are directed at traditional trade agreement concerns about discrimination, it is clear that violations of provisions like Article 2 do not require findings of discrimination. ${ }^{36}$

However, we argue below that the distinction between discrimination analysis and 'rationality' analysis is not as great as it might at first appear. Hudec suggested this as well:

The place to start is to recognize that the word 'discrimination' that we use in all these cases is a normative term expressing a judgment of disapproval. When we see a regulation that has the effect of putting foreign goods at a competitive disadvantage, the neutral descriptive term for that situation is that the regulation has a 'differential impact.' If we think there is nothing wrong with that differential impact, we continue to call it a differential impact. If we think there is something wrong about the differential impact, then we call it discrimination.

Thus, differential impact that has adequate rational justification in terms of achieving a regulatory objective is not understood as discrimination. But this leaves open the question of whether treatment that does not result in differential impact, but that lacks adequate rational justification, is acceptable or not. Does WTO law impose a 'free-standing' requirement of rationality in regulation, regardless of whether there are differential impacts? The Continued Suspension case does not present this specific question, because it is widely assumed that the European limits on hormones have a differential impact on Canadian and US producers. But this differential impact was not a formally salient feature of the argument.

A close analysis of the way in which the AB has applied SPS Articles 2.2., 5.1, and 5.7 (the 'SPS 2.2/5.1/5.7 Complex'), and a comparison with the way the AB

35 See Robert E. Hudec (2003), 'Science and post-discriminatory WTO law', 26:2 Boston College International and Comparative Law Review 185.

36 Ibid. at 187. 
has applied GATT Articles III, XI, and XX (the 'GATT Article III/XX Complex'), helps illuminate the types of cases that might be covered by the SPS Agreement that are not covered by the GATT. Interestingly, from the standpoint of this relationship, a measure that complies with the SPS Agreement, including the SPS 2.2/5.1/ 5.7 Complex, is presumed under SPS Article 2.4 'to be in accordance with the obligations of the Members under the provisions of GATT 1994 which relate to the use of sanitary or phytosanitary measures, in particular the provisions of Article XX(b)'.

Therefore, a measure that complies with the SPS Agreement is presumed not to illegally discriminate under Article III of GATT. Of course, SPS Articles 2.3 and 5.5 contain their own antidiscrimination prohibitions, making it seem ordinarily unnecessary as a matter of judicial economy to test a measure for discrimination under Article III where it complies with the SPS Agreement. While these antidiscrimination prohibitions have different formulations, the differences are unlikely to produce different outcomes. Furthermore, SPS Article 2.4 only sets up a presumption, which we may assume is rebuttable. But we still have the question, what is prohibited by the SPS 2.2/5.1/5.7 Complex that is not already prohibited by the national-treatment provisions of either the SPS Agreement or GATT ?

The remainder of this section analyzes the substantive components and effects of the additional disciplines on domestic regulation in the SPS 2.2/5.1/5.7 Complex, beyond the disciplines that result from the GATT III/XX Complex. In Section 4, we discuss public policy and economic dimensions of the additional disciplines.

\section{National Treatment Jurisprudence: The GATT III/XX Complex}

Before the inception of the WTO in 1995, the only multilateral trade discipline on domestic product regulation was provided by Articles III and XI of GATT. Article III requires national treatment, and Article XI applies, where Article III does not apply, to prohibit quantitative restrictions on imports (and exports). We will not discuss Article XI in further detail. Article XX provides a range of exceptions for measures that may otherwise violate Article III. Let us begin with the text of Articles III: 1 and 4 of the GATT, which provide:

1. The contracting parties recognize that internal taxes and other internal charges, and laws, regulations and requirements affecting the internal sale, offering for sale, purchase, transportation, distribution or use of products, and internal quantitative regulations requiring the mixture, processing or use of products in specified amounts or proportions, should not be applied to imported or domestic products so as to afford protection to domestic production. [emphasis added] 4 . The products of the territory of any contracting party imported into the territory of any other contracting party shall be accorded treatment no less favourable than that accorded to like products of national origin in respect of all laws, regulations and requirements affecting their internal sale, offering for sale, purchase, transportation, distribution or use. 
This language has been interpreted in several GATT and WTO cases. In its first report, Japan-Alcoholic Beverages, the $\mathrm{AB}$ declared that the broad purpose of Article III is to prohibit 'protectionism, ${ }^{37}$ a concept that it did not define. It also rejected Hudec's 'aims-and-effects' approach to the obligation of national treatment, at least as a search for subjective intent. ${ }^{38}$ It refused to see any issue of the subjective intent of the member state in Article III determination:

[I]t does not matter that there may not have been any desire to engage in protectionism in the minds of the legislators or the regulators who imposed the measure. It is irrelevant that protectionism was not an intended objective if the particular tax measure in question is nevertheless, to echo Article III:1, applied to imported or domestic products so as to afford protection to domestic production. ${ }^{39}$

The $\mathrm{AB}$ stated that 'it is possible to examine objectively the underlying criteria used in a particular tax measure, its structure, and its overall application, to ascertain whether it is applied in a way that affords protection to domestic products' ${ }^{40}$ (emphasis added). As noted above, this search for the underlying structure is comparable to the search for a scientific basis under the SPS Agreement. The EC-Asbestos AB Report reiterated that the text of Article III:4 reflected the general principle of paragraph 1 of Article III in seeking 'to prevent Members from applying internal taxes and regulations in a manner which affects the competitive relationship, in the marketplace, between the domestic and imported products involved, "so as to afford protection to domestic production", ${ }^{41}$

37 'The broad and fundamental purpose of Article III is to avoid protectionism in the application of internal tax and regulatory measures. More specifically, the purpose of Article III "is to ensure that internal measures not be applied to imported and domestic products so as to afford protection to domestic production". Toward this end, Article III obliges Members of the WTO to provide equality of competitive conditions for imported products in relation to domestic products ... Article III protects expectations not of any particular trade volume but rather of the equal competitive relationship between imported and domestic products ...' Japan - Taxes on Alcoholic Beverages (Japan-Alcoholic Beverages II), WT/DS8/ AB/R, WT/DS10/AB/R, WT/DS11/AB/R, adopted 1 November 1996, at p. 16.

38 See Appellate Body Report, Japan-Alcoholic Beverages II, at p. 27: "This third inquiry under Article III:2, second sentence, must determine whether "directly competitive or substitutable products" are "not similarly taxed" in a way that affords protection. This is not an issue of intent. It is not necessary for a Panel to sort through the many reasons legislators and regulators often have for what they do and weigh the relative significance of those reasons to establish legislative or regulatory intent'; and at p. 29: 'Although it is true that the aim of a measure may not be easily ascertained, nevertheless its protective application can most often be discerned from the design, the architecture, and the revealing structure of a measure.' See Robert E. Hudec (1998), 'GATT/WTO Constraints on National Regulation: Requiem for an Aims and Effects Test', 32 International Lawyer 619. See also Amelia Porges and Joel P. Trachtman (2003), 'Robert Hudec and Domestic Regulation: The Resurrection of "Aim and Effects", 37 Journal of World Trade (commissioned paper).

39 Appellate Body Report, Japan-Alcoholic Beverages II, at p. 28.

40 Ibid., at p. 29.

41 Appellate Body Report, European Communities-Measures Affecting Asbestos and AsbestosContaining Products (EC-Asbestos), WT/DS135/AB/R, adopted 5 April 2001, at para. 98. 
For a violation of Article III:4 to be established, the complaining Member must prove that the measure at issue is a 'law, regulation, or requirement affecting their internal sale, offering for sale, purchase, transportation, distribution, or use'; that the imported and domestic products at issue are 'like products'; and that the imported products are accorded 'less favorable' treatment than that accorded to like domestic products. ${ }^{42}$

\section{Imported and domestic like products}

The prohibition against discrimination in the national-treatment obligation can apply only when imported and domestic products are 'like'. The majority of the $\mathrm{AB}$ in EC-Asbestos found that 'likeness' under Article III:4 is, 'fundamentally, a determination about the nature and extent of a competitive relationship between and among products'. ${ }^{43}$ To perform such an assessment, the AB recalled that four basic criteria, derived from the Border Tax Adjustment report - (i) the physical properties of the products in question; (ii) their end-uses; (iii) consumer tastes and habits vis-à-vis those products; and (iv) tariff classification ${ }^{44}$ - are to be used as tools in the determination of this competitive relationship between products. These criteria do not exhaust inquiry. ${ }^{45}$

The competitive relationship between imports and domestic goods is the determinant of likeness. 'If there is - or could be - no competitive relationship between products, a Member cannot intervene, through internal taxation or regulation, to protect domestic production. ${ }^{46}$ This competitive relationship is to be determined using the basic criteria of the Border Tax Adjustments report. The balancing of the criteria identified in the Border Tax Adjustments report is intended to approximate the competitive relationship between the relevant goods. A more precise and refined, and quantitative, measure of whether a competitive relationship exists is the economic concept of cross-elasticity of demand.$^{47}$ Roughly speaking, this measures the extent to which a rise in the price of one good induces a shift in demand by

42 Appellate Body Report, Korea-Measures Affecting Imports of Fresh, Chilled and Frozen Beef (Korea-Various Measures on Beef), WT/DS161/AB/R and WT/DS169/AB/R, adopted 10 January 2001, at para. 133.

43 Appellate Body Report, EC-Asbestos, at para. 99. Note the different opinion with regard to the very specific aspects mentioned in para. 154. See the analysis of the Asbestos report in Henrik Horn and J.H.H. Weiler (2003), 'European Communities - Measures Affecting Asbestos and Asbestos-Containing Products', in Henrik Horn and Petros C. Mavroidis (eds.), The WTO Case Law of 2001: The American Law Institute Reporters' Studies, Cambridge: Cambridge University Press.

44 Working Party Report, Border Tax Adjustments, adopted 2 December 1970, BISD 18S/97.

45 Appellate Body Report, EC-Asbestos, at para. 101.

46 Ibid., at para. 117.

47 See, for instance, the criteria of cross-elasticity of demand to determine whether imported and domestic products are directly competitive or substitutable in the Appellate Body Report in Japan-Alcoholic Beverages II, at p. 26, or in Appellate Body Report, Korea-Taxes on Alcoholic Beverages (Korea-Alcoholic Beverages ), WT/DS75/AB/R, WT/DS84/AB/R, adopted 17 February 1999, at paras. 108-124, or in the Appellate Body Report, United States - Transitional Safeguard Measure on Combed Cotton Yarn from Pakistan (US-Cotton Yarn), WT/DS192/AB/R, adopted 5 November 2001, paras. 89-102. 
consumers to the other good being tested. Although not as accurate or refined as using the cross elasticity of demand to determine a competitive relationship, the qualitative Border Tax Adjustment factors may be used to assess a competitive relationship between products.

The Border Tax Adjustment test, emphasizing competitive relationships as specified by the $\mathrm{AB}$ in Asbestos, is relatively ignorant of factors that motivate regulation. An alternative approach to like products would examine the rationality of the domestic regulatory distinction that results in differential regulatory treatment - determining whether to respect the rationality of the national regulatory categories and thus to accept that the products are not 'like'. This search for the rationality of the domestic regulation, if effected, would be comparable to the search for a scientific basis in the SPS Agreement.

The economic theory of regulation suggests that regulation is necessary precisely where consumers cannot adequately distinguish relevant goods - where, but for the regulation, they would be in close competitive relation. Thus, a competitive relationship test for likeness could often result in a finding that goods that differ by the parameter addressed by regulation are indeed like, and should be treated the same. ${ }^{48}$ Hence, many domestic regulations would prima facie violate Article III - as like products would be treated differently, they would need the justification of Article XX to be WTO-compatible. This is why the AB's two-step analysis, used first in Korea-Various Measures on Beef ${ }^{49}$ and described more precisely in paragraph 100 of the EC-Asbestos decision, discussed hereafter, is important. Note that it is important in order to ensure that rational regulation with differential impact does not violate Article III.

\section{Less favorable treatment}

The less-favorable-treatment criterion involves an 'effects test'. In Korea-Various Measures on Beef, the $\mathrm{AB}$ reversed the Panel, which had concluded that a regulatory distinction based exclusively on the origin of the product necessarily violated Article III. The AB emphasized the fact that 'differential treatment' may be acceptable, so long as it is 'no less favorable'. Article III only prohibits discriminatory treatment, which 'modifies the conditions of competition in the relevant market to the detriment of imported products'. ${ }^{\mathbf{5 0}}$

Is this 'modification of the conditions of competition to the detriment of imported products' the benchmark to assess the existence of 'protectionism' condemned by Article III? In EC-Asbestos, the AB reiterated that the 'broad and fundamental purpose' of the obligation of national treatment (Article III GATT) is 'to avoid' the application of 'protectionist' internal measures; this determination is based on whether such internal measures are applied in a manner that affects the

48 Moreover, if it is true that consumers would not consider them interchangeable, then some may say that the regulation was not necessary.

49 Appellate Body Report, Korea-Various Measures on Beef, at paras. 133-149.

50 Ibid., at para. 137. 
competitive relationship, in the marketplace, between the domestic and imported products involved, 'so as to afford protection to like domestic production' ${ }^{51}$ This decision established a two-step analysis, wherein the first step requires a determination whether like products are treated differently, and the second step determines whether this differential treatment amounts to 'less favorable treatment'.

In paragraph 100 of its opinion in EC-Asbestos, the $\mathrm{AB}$ made the following statement:

A complaining Member must still establish that the measure accords to the group of 'like' imported products 'less favourable treatment' than it accords to the group of 'like' domestic products. The term 'less favourable treatment' expresses the general principle, in Article III:1, that internal regulations 'should not be applied ... so as to afford protection to domestic production. ${ }^{52}$

And as the $\mathrm{AB}$ had stated in Korea-Various Measures on Beef, ' a formal difference in treatment between imported and like domestic products is thus neither necessary, nor sufficient, to show a violation of Article III:4'. Whether or not imported products are treated less favorably than like domestic products should be assessed instead by examining whether a measure modifies the conditions of competition in the relevant market to the detriment of imported products as a class. Thus, it is not enough to find a single foreign like product that is treated differently from a single domestic like product. Rather, the class of foreign like products must be treated less favorably than the class of domestic like products. In order for this to occur, it would seem necessary that the differential regulatory treatment be predicated, either intentionally or unintentionally, on the foreign character of the product. However, in Korea-Various Measures on Beef, the AB made clear that differential treatment based on nationality, alone, would not necessarily amount to 'less favorable' treatment. ${ }^{53}$ Thus, a violation would only occur if after respecting the legitimate (non-national origin) categories, the measure is still found to treat the import less favorably.

As the $\mathrm{AB}$ applies this principle in future cases, we may be able to determine whether a regulation allowing for distinctions (different treatment) based on nonprotectionist prudential goals and considerations is captured by the less-favorabletreatment provision and therefore condemned by the application of Article III just because it affects negatively market opportunities for imports. It may be that the less-favorable-treatment criterion only condemns protectionist or other

51 Appellate Body Report, EC-Asbestos, at paras. 96 and 98: 'in endeavoring to ensure "equality of competitive conditions", the "general principle" in Article III seeks to prevent Members from applying internal taxes and regulations in a manner which affects the competitive relationship, in the marketplace, between the domestic and imported products involved, "so as to afford protection to domestic production",'.

52 Ibid., at para. 100.

53 Appellate Body Report, Korea-Various Measures on Beef, at para. 134. 
illegitimate regulatory distinctions. If so, then Article III would include a search for legitimate regulatory rationales comparable to the search for a scientific basis under the SPS Agreement; the gap between discrimination and post-discrimination would be narrow. It is worth noting that a similar consideration motivated the aims-and-effects test. ${ }^{54}$ It is also possible that 'less favorable treatment' could be interpreted broadly so as to include any market distortion favoring domestic products, even if the goal, object, and purpose of the measure are not protectionist. In such case, reliance on Article XX to justify such measure would remain possible.

Since Japan-Alcohol, the AB has purported to reject inquiry into the subjective intent of governments. However, it allowed in that case that intent might be discerned from the objective structure of a regulatory measure. Discussing the Reformulated Gasoline decision, Hudec noted that where tribunals are concerned with the intent of regulators, they do not examine subjective intent:

The standard way of deciding such purpose questions in GATT law, US Constitutional law, and European Community law is by reference to what I usually refer to as 'objective indicators.' The objective indicators, when applied, look a great deal like second-guessing the judgments of governments. In general, one looks to whether the measure was really necessary to obtain the declared goal. For example, one examines whether less restrictive alternatives were available and not used, or whether the decision in areas affecting foreign goods is in fact consistent with the kinds of decisions that are taken in analogous areas which affect sellers of domestic goods. ${ }^{55}$

We suggest below that the scientific-evidence test of the SPS Agreement may be understood in just these terms: as an objective indicator of protectionist intent. This is just a possible characterization, but it is especially appealing assuming that the scientific-evidence test is not a free-standing rationality requirement, independent of trade effects - that is, assuming that the inquiry is not just into aim, but also into effects. Even if the scientific-evidence test is doctrinally a free-standing rationality requirement, once we consider the remedies available for violation, we might see that trade effects are considered.

To conclude this discussion, we may say that an Article III:4 case is comprised of the following elements: (i) a product comparison to determine whether the imported goods are 'like' a domestically produced good, (ii) a treatment comparison to determine whether the imported goods are treated 'less favorably', and (iii) a potential exercise of discretion to determine whether the less favorable treatment is of the requisite type. What could be involved in the last determination? Assuming that the first examination of 'less favorable treatment' considers the effects of the domestic measure under consideration, there is only one

54 See Hudec, supra note 35; and Frieder Roessler (1996), 'Diverging Domestic Policies and Multilateral Trade Integration', in Robert E. Hudec and Jagdish Bhagwati (eds.), Fair Trade and Harmonization, Pre-requisite for Free-Trade, Vol. II, Cambridge, MA: MIT Press.

55 Hudec, supra note 35, at 193. 
other area for consideration: the legitimacy of the aim of the domestic measure. Again, this is the same consideration as that included in the 'post-discriminatory' SPS Agreement.

\section{Article XX Necessity}

Assuming that a violation of Article III :4 is found, this does not necessarily mean that the subject measure will constitute a violation of GATT. Rather, measures may be eligible for an exception under Article XX. We will examine Article XX(b), as it relates closely to the SPS context. In particular, we may see in Article XX(b) a type of rationality analysis that presages and parallels the scientific-basis requirements of the SPS 2.2/5.1/5/7 Complex.

Since its inception, GATT has always recognized that prudential government policies may justify measures contrary to basic GATT market-access rules. Traditionally in GATT, the exceptional provisions of Article $\mathrm{XX}(\mathrm{b})$ and (d) are available to justify measures - otherwise incompatible with other GATT provisions - if they are 'necessary.' This has been interpreted to require that the country invoking these exceptions demonstrate that no other WTO-compatible or less-restrictive alternative was reasonably available to pursue the desired policy goal. ${ }^{56}$

The Article XX necessity test was addressed in Korea-Various Measures on Beef, where Korea attempted to justify its dual retail system for beef by arguing the need for compliance with a domestic regulation against fraud. The AB interpreted the necessity test of Article XX(d) to imply a requirement for balancing among at least three variables:

In sum, determination of whether a measure, which is not 'indispensable', may nevertheless be 'necessary' within the contemplation of Article $\mathrm{XX}(\mathrm{d})$, involves in every case a process of weighing and balancing a series of factors which prominently include the contribution made by the compliance measure to the enforcement of the law or regulation at issue, the importance of the common interests or values protected by that law or regulation, and the accompanying impact of the law or regulation on imports or exports. ${ }^{57}$

After reiterating that WTO Members have the right to determine for themselves the level of enforcement of their domestic laws ${ }^{58}$ (a concept close to the 'appropriate level of protection' referred to in the SPS Agreement), the AB called for an authentic balancing and weighing of (at least) these variables: 'The more vital or important those common interests or values are, the easier it would be to accept as

56 See GATT Panel Report, United States - Section 337 of the Tariff Act of 1930 (US-Section 337), adopted 7 November 1989, BISD 36S/345, at para. 5.26; GATT Panel Report, United States - Measures Affecting Alcoholic and Malt Beverages (US-Malt Beverages), adopted 19 June 1992, BISD 39S/206), at para. 5.52; and GATT Panel Report, Thailand-Restrictions on Importation of and Internal Taxes on Cigarettes (Thailand-Cigarettes), adopted 7 November 1990, BISD 37S/200, at para. 223.

57 Appellate Body Report, Korea-Various Measures on Beef, at para. 164.

58 Ibid., at para. 177. 
" necessary" a measure designed as an enforcement instrument' ; 59 'The greater the contribution [to the realization of the end pursued], the more easily a measure might be considered to be "necessary" ", ${ }^{60}$ or: "A measure with a relatively slight impact upon imported products might more easily be considered as "necessary" than a measure with intense or broader restrictive effects. ${ }^{\prime 1}$ Note the relationship between these variables and the requirement for a scientific basis under the SPS 2.2/5.1/5.7 Complex.

It is not clear how these variables affect each other, nor is it clear how their balancing would affect the final determination that a measure qualifies under Article XX and how this new test relates to the traditional 'least trade restrictive alternative reasonably available' test. Yet in EC-Asbestos, the AB tried to reconcile its new balancing test with the traditional least-trade-restrictive-alternative test. For the AB, the balancing referred to in Korea-Various Measures on Beef is part of the determination of whether a WTO-compatible or less-trade-restrictive alternative exists to obtain the end pursued (as called for by the traditional necessity test of Article XX(b)). ${ }^{62}$ In light of France's chosen level of protection, and noting that the protection of human life is vital and important to the highest degree, ${ }^{63}$ the $E C$-Asbestos $\mathrm{AB}$ report concluded that ' $[\mathrm{t}]$ he remaining question, then, is whether there is an alternative measure that would achieve the same end and that is less restrictive of trade than a prohibition' ${ }^{64}$

In Korea-Various Measures on Beef the possibility of an unreasonable or inauthentic policy goal was raised:

The application of such [different] measures for the control of the same illegal behaviour for like, or at least similar, products raises doubts with respect to the objective necessity of a different, much stricter, and WTO-inconsistent enforcement measure. ${ }^{65}$

This search for reasonableness or authenticity has a direct parallel in the SPS 2.2/5.1/5.7 Complex, as well as in Article 5.5 of the SPS Agreement.

59 Ibid., at para. 162 .

60 Ibid., at para. 163.

61 Ibid.

62 Appellate Body Report, EC-Asbestos, at para. 172: 'We indicated in Korea-Beef that one aspect of the "weighing and balancing process ... comprehended in the determination of whether a WTO-consistent alternative measure" is reasonably available is the extent to which the alternative measure "contributes to the realization of the end pursued". In addition, we observed, in that case, that " $[\mathrm{t}]$ he more vital or important [the] common interests or values" pursued, the easier it would be to accept as "necessary" measures designed to achieve those ends. In this case, the objective pursued by the measure is the preservation of human life and health through the elimination, or reduction, of the well-known, and life-threatening, health risks posed by asbestos fibres. The value pursued is both vital and important in the highest degree. The remaining question, then, is whether there is an alternative measure that would achieve the same end and that is less restrictive of trade than a prohibition.'

63 Ibid.

64 Ibid.

65 Appellate Body Report, Korea-Various Measures on Beef, at para. 172. 
In Brazil-Tyres, it was seen that this type of balancing test may be very demanding to apply in technical terms, and that panels may avoid carrying out these tests as described. ${ }^{66}$ In fact, these tests may require the panel to second-guess some of the public-policy evaluations that governments often carry out in order to determine their measures. This type of second-guessing is precisely the type of judicial exercise that has been rejected under the scientific-basis provisions of the SPS Agreement. Indeed, the AB decision in the Continued Suspension case may be understood along parallel lines as an interpretation of the SPS Agreement that limits the scope of judicial scrutiny of national use of science as a basis for public policy.

\section{Post-discrimination rules and jurisprudence}

We have already discussed the main relevant features of the SPS Agreement, as applied in the Continued Suspension case. The SPS Agreement should be understood, to some extent, as a conversion of Article XX of GATT from a defense applicable only after a primary violation is established to a positive obligation, and an expansion of its disciplines. Its drafters were concerned with the need to (1) expand the scientific and procedural requirements for a Member to impose an SPS measure and (2) encourage reliance on and participation in international standardsetting bodies. Yet the obligations of the SPS Agreement stand alone, and the Panel in EC-Hormones stated that since the SPS Agreement adds to Articles III, XI, and $\mathrm{XX}$ of GATT, there is no obligation to prove a violation of Articles III or XI before the SPS Agreement can be invoked. ${ }^{67}$ The SPS obligations are additional to the GATT obligations, except to the extent that they may be doctrinally coterminous with or included in the GATT obligations.

In all cases where a standard other than an international standard is used, the Member imposing an SPS measure must be able to rely on a relevant risk assessment pursuant to Article 5.1 to 5.4 of the SPS Agreement, unless there is insufficient

66 Chad Bown and Joel P. Trachtman (2009), 'Brazil-Measures Affecting Imports of Retreaded Tyres: A Balancing Act', 8 (Special Issue 1) World Trade Review 85.

67 In EC-Hormones (US), the European Communities submitted that 'the "substantive" provisions of the SPS Agreement can only be addressed if recourse is made to GATT Article XX(b), i.e., if, and only if, a violation of another provision of GATT is first established'. The Panels rejected this argument, indicating as follows: 'The SPS Agreement contains, in particular, no explicit requirement of a prior violation of a provision of GATT which would govern the applicability of the SPS Agreement, as asserted by the European Communities' (para. 8.36). The Panels added: 'on this basis alone we cannot conclude that the SPS Agreement only applies, as Article XX(b) of GATT does, if, and only if, a prior violation of a GATT provision has been established. Many provisions of the SPS Agreement impose "substantive" obligations which go significantly beyond and are additional to the requirements for invocation of Article $\mathrm{XX}(\mathrm{b})$. These obligations are, inter alia, imposed to "further the use of harmonized sanitary and phytosanitary measures between Members" and to "improve the human health, animal health and phytosanitary situation in all Members". They are not imposed, as is the case of the obligations imposed by Article XX(b) of GATT, to justify a violation of another GATT obligation (such as a violation of the non-discrimination obligations of Articles I or III)' (para. 8.38). Panel Report, EC Measures Concerning Meat and Meat Products (Hormones) - Complaint by the United States (EC-Hormones (US)) WT/DS26/R/USA, adopted 13 February 1998 as modified by the Appellate Body Report, WT/DS26/AB/R, DSR 1998:III, p. 699. 
evidence in accordance with Article 5.7. These requirements ${ }^{68}$ were interpreted in each of the four prior cases under the SPS Agreement: EC-Hormones, ${ }^{69}$ Australia-Salmon, ${ }^{70}$ Japan-Agricultural Products, ${ }^{71}$ and EC-Biotech. ${ }^{72}$

\section{The relationship between discrimination and post-discrimination disciplines}

A comparison between the disciplines of the GATT III/XX Complex and the SPS 2.2/5.1/5.7 Complex can only operate at a rather high level of generality. However, the preceding discussion provides a basis for showing, in realistic terms, the actual operation of these tests and how they relate to one another. Their general purpose appears to be the same: to discipline protectionist national regulation.

Imagine a conversation between two trade negotiators. After agreeing on tariff reduction-based liberalization, they are concerned about defection from the agreed commitments. They agree not to discriminate in the application of domestic tax and regulatory measures (i.e. abide by national treatment) but recognize that there is both de jure and de facto discrimination. De facto discrimination is more difficult to identify reliably, because it is possible to write facially general rules that have differential, and protectionist, effects.

The negotiators decide that the history of application of national-treatment rules provides too much flexibility to judges to determine whether a national measure is impermissibly de facto discriminatory, and inevitably requires the judges to evaluate the good faith, or the prudential regulatory basis, of the domestic regulation. It is possible, though, to give the judges more guidance, and to discipline a broader range of national measures where it may otherwise be difficult to identify discrimination. In addition to prohibiting discrimination, the negotiators agree, they will also make sure that a certain category of regulatory measures where they expect a high level of protectionism - domestic political pressure for protection - is supported by a prudential regulatory basis: that it has an objective and sufficient non-protectionist 'aim' or purpose. They agree that all regulation in

68 In Australia-Salmon, the Appellate Body stated: 'On the basis of [the] definition [prescribed in the first part of paragraph 4 of Annex A], we consider that, in this case, a risk assessment within the meaning of Article 5.1 must: (1) identify the diseases whose entry, establishment or spread a Member wants to prevent within its territory, as well as the potential biological and economic consequences associated with the entry, establishment or spread of these diseases; (2) evaluate the likelihood of entry, establishment or spread of these diseases, as well as the associated potential biological and economic consequences; and (3) evaluate the likelihood of entry, establishment or spread of these diseases according to the SPS measures which might be applied.' Appellate Body Report, Australia-Salmon, WT/DS18/AB/R, adopted 16 November 1998 , at para. 121.

69 Appellate Body Report, EC-Hormones.

70 Appellate Body Report, Australia-Salmon.

71 Appellate Body Report, Japan-Measures Affecting Agricultural Products (Japan-Agricultural Products II), WT/DS76/AB/R, adopted 19 March 1999.

72 European Communities - Measures Affecting the Approval and Marketing of Biotech Products (EC-Biotech), WT/DS291,292,293/R, adopted 21 November 2006. 
this category will be required to have a scientific basis. As discussed in Section 1, this can be justified from an economic perspective insofar as the presumption is that there are market failures because of imperfect information or negative consumption or production externalities (from pests, diseases, etc.).

Although it might be argued à la Hudec that the SPS 2.2/5.1/5.7 Complex goes beyond protectionism, a reasonable argument can be made that it was not intended to do so, and that it has been interpreted in a way that does not do so. If this is correct, it might well be asked why the SPS 2.2/5.1/5.7 Complex was considered necessary to supplement the GATT III/XX Complex. There are two potential responses. The first can be expressed in a single word: agriculture. ${ }^{73}$ Given the intent to begin a process of liberalization of agricultural imports under the Agreement on Agriculture, it made sense in 1994 to develop also a specialized set of disciplines on domestic regulation in the field of agriculture. Perhaps it was hoped that this specialized set of disciplines would also respond to the second possible purpose: to fill gaps in the disciplines of the GATT III/XX Complex.

There are three distinct types of gaps in the GATT III/XX Complex.

First, it may be difficult from an evidentiary or burden-of-proof standpoint to prove the requisite discrimination. One response to this first gap would be to establish a 'presumption' of discrimination, or a proxy for an actual finding of discrimination. The scientific-basis requirement of the SPS 2.2/5.1/5.7 Complex may be understood to fill this gap (the 'evidentiary gap'). In economic terms, a (minimum) test is imposed that increases the likelihood that the objective of the national measure is to address a consumption externality, as opposed to improving the terms of trade, shifting rents, etc.

Second, assuming for a moment that the differentiating factor in the GATT III/XX complex between legal and illegal domestic measures is the legitimacy or prudential basis of the regulatory measure, a gap in the GATT III/XX Complex from a trade-liberalization standpoint is the possibility that measures that do not 'discriminate' in terms of aim and thus are not thereby prohibited nevertheless have a substantial and unjustified differential effect (see discussion above). Because it might be assumed that this type of differential effect is only sustainable against those who are not adequately represented in the domestic political process, we might term this effect the 'representation gap'. While it might be appropriate to exclude foreign interests from the domestic political process addressing a local consumption externality, it may also be appropriate to address any negative external consequences through international negotiations and perhaps an international legal rule.

Third, there may be circumstances in which the domestic regulation is inefficient. This may occur because domestically enfranchised persons who are harmed are not sufficiently harmed to induce them to take sufficient political action to

73 It should be noted, of course, that the TBT Agreement, dealing with non-SPS technical regulations and standards, also addresses 'post-discriminatory' measures. 
terminate the domestic regulation. As Mancur Olson showed, political action can be a public good that is under-supplied. We might term this effect the 'efficiency gap'. The solution may involve external pressure and engagement in negotiations that center on the substantive content/level of domestic product regulation and that result in either harmonization or mutual recognition of standards. It might alternatively involve a process-of-information provision and 'learning' that is aimed at changing the incentives of groups to engage in the standards setting (political) process and/or the views of consumers regarding the appropriate level of regulation.

As recounted above, the $\mathrm{AB}$ has said that it does not consider the legislative ' aim' in connection with measures evaluated under Article III. However, as a practical matter, panels and the $\mathrm{AB}$ have done so, even after Japan-Alcoholic Beverages. ${ }^{74}$ But we might say that the SPS 2.2/5.1/5.5 Complex does what the $\mathrm{AB}$ suggested: it calls for an examination of the objective structure of the regulation - in this case, whether it is objectively justified by scientific evidence - in order to deduce whether it is motivated by illegitimate protectionism.

It must be conceded that discrimination is not easily defined, and that its determination often cannot avoid judicial evaluation of national regulatory categories. In fact, determination of difficult cases of de facto discrimination requires judicial evaluation of national regulatory categories. Thus, it is simply incorrect to say that pre-1995 GATT law did not involve critique of national regulatory categories. The distinction between discrimination regulation and post-discrimination regulation is therefore nuanced. Hudec cataloged the distinctions as follows:

The second-guessing of government regulatory decisions that goes on in a trade discrimination case occurs in a much different setting from, and for a much different purpose than, the second-guessing that seems so unwarranted in the post-discriminatory part of the SPS Agreement ... First, the typical discrimination case concerns a situation in which foreign goods are in fact being placed at a disadvantage $v i s-\grave{a}$-vis domestic goods. There is a differential impact, the central problem at which the international trading system is directed. Second, a discrimination case concerns a question of wrongful purpose, not just a mistake in judgment. Third, discrimination cases involve a situation in which government wrongdoing is a highly possible element - not probable, but possible. ${ }^{75}$

The first distinction noted by Hudec - that discrimination cases necessarily involve differential effects, while post-discrimination cases do not - may be more important as form than as substance. Although in principle an SPS measure may lack a scientific basis yet not produce differential effects, none of the postdiscrimination cases decided so far has been argued to involve equivalent effects on

74 Amelia Porges and Joel P. Trachtman (2003), 'Robert Hudec and Domestic Regulation: The Resurrection of "Aim and Effects", 37 Journal of World Trade.

75 Hudec, supra note 35 , at 194 . 
domestic and imported goods. Perhaps there is an implicit understanding among the member states that would require differential effects as a basis for legitimate litigation under these provisions, even where the formal language of the SPS Agreement does not require differential effects. To the extent that SPS measures are intended to address consumption externalities, then differential effects (in the national-treatment sense) would arise to the extent that imported products are treated differently and adversely because they generate consumption externalities greater than those generated by domestic products. Under these circumstances, differential effects in the market should not be a sufficient basis for a finding of violation of Article III, nor should they be a basis for a finding of violation of the SPS Agreement. Rather, in both cases, the requisite finding appears to be one of illegitimacy of purpose, rather than disproportionality of effects.

Hudec's second distinction, that discrimination cases necessarily involve a prohibited aim - protectionism - is also not necessarily persuasive: as the riskassessment requirement has evolved under the WTO, it increasingly can be seen as a proxy test for protectionist aim. According to this perspective, scientific-basis requirements address the evidentiary gap: they address the question of whether there is indeed a consumption externality of the type that is amenable to government reaction. Necessity tests may be understood in the same way. After all, where governments act irrationally in a way that has protective effects, one possible inference is that there is a protective aim. It is not the only possible inference, but it may be an attractive one.

Hudec's third distinction seems to track the second one: government wrongdoing in the form of protectionist intent may be identified using direct evidence, or using proxy evidence. As noted above, protectionist intent is rarely identified using direct evidence. Rather, as the AB stipulated in Japan-Alcoholic Beverages, it may be inferred from the objective structure of the measure. In this light, we might understand the SPS 2.2/5.1/5.7 Complex as a refined legislatively designed mechanism for inference of protectionism based on the structure of the measure. This is not the only way to understand it, but it is an increasingly plausible way to understand it.

So, can the SPS 2.2/5.1/5.7 Complex be understood as a subtle, rule-based (as opposed to standard-based) prescription for evaluation of the aim of a national measure? It seems to evaluate directly the extent and quality of the nonprotectionist aim: by asking whether the measure is based on a risk assessment, it asks whether an agreed predicate for non-protectionist SPS measures has been satisfied. It might alternatively be understood as establishing a presumption of a protectionist aim where the risk-assessment criterion has not been met.

While a measure may be found illegal under the SPS 2.2/5.1/5.7 Complex even where it has no trade effects, the Dispute Settlement Understanding, by limiting retaliation to the level of nullification or impairment - to the level of trade effects - may be understood as establishing an effective requirement of trade effects, in a legal-realist sense. 
Table 1. Key features of the SPS and GATT Art. III/XX disciplines

\begin{tabular}{|c|c|c|}
\hline & SPS $2.2 / 5.1 / 5.7$ & GATT III/XX \\
\hline $\begin{array}{l}\text { Domain of } \\
\text { application }\end{array}$ & SPS measures (agricultural products) & Domestic taxation and regulation \\
\hline $\begin{array}{l}\text { Appropriate level } \\
\text { of protection }\end{array}$ & Member-state discretion & Member-state discretion \\
\hline $\begin{array}{l}\text { Required } \\
\text { prudential basis }\end{array}$ & $\begin{array}{l}\text { Scientific; (implicit) presumption } \\
\text { of a market failure justifying } \\
\text { product regulation }\end{array}$ & Tax/regulatory justification \\
\hline $\begin{array}{l}\text { Standard of } \\
\text { review/deference }\end{array}$ & $\begin{array}{l}\text { Coherent reasoning; respectable science; } \\
\text { objectively justifiable; sufficient warrant } \\
\text { for measure; need not reflect a 'majority } \\
\text { view' or existing international norms }\end{array}$ & $\begin{array}{l}\text { Unspecified in Art. III; plausible } \\
\text { nonprotectionist aim; in Art. XX, } \\
\text { balancing test includes contribution }\end{array}$ \\
\hline Aim & $\begin{array}{l}\text { Scientific evidence as proxy for aim; } \\
\text { presumption that SPS measures address } \\
\text { negative externalities }\end{array}$ & $\begin{array}{l}\text { Direct evidence rejected in } \\
\text { Japan-Alcohol; indirectly derived } \\
\text { from objective structure of measure; } \\
\text { possibly embedded in like-products } \\
\text { determination; or less- } \\
\text { favorable-treatment determination; } \\
\text { or in necessity under Korea-Beef. }\end{array}$ \\
\hline Effect & Not explicitly addressed & $\begin{array}{l}\text { Possibly embedded in like-products } \\
\text { determination; or less-favorable- } \\
\text { treatment determination; or in } \\
\text { necessity under Korea-Beef }\end{array}$ \\
\hline Remedy & Determined by trade effects & Determined by trade effects \\
\hline
\end{tabular}

Table 1 summarizes the salient features of the comparison between the SPS 2.2/5.1/5.7 Complex and the GATT III/XX Complex. For convenience, the table also summarizes some of the key differences between the possible welfare-enhancing justifications for intervention in the SPS area as distinct from more general motivations for taxation/regulation of products circulating in the economy.

\section{Concluding remarks}

The trade dispute between the US and Canada, and the EU, on hormones and beef has been one of the longest-running conflicts in the trading system - the first formal dispute dates back to 1988 when the US brought a case to GATT (invoking the then TBT agreement). Indeed, one of the drivers for the negotiation of the SPS Agreement was this dispute. If evaluated on the basis of resolving the dispute, it would appear that the addition of specific disciplines on the use of SPS measures has not (yet) been successful. However, the latest AB report has clarified how the disciplines of the SPS Agreement should be applied and in the process made clearer how the Agreement goes beyond the GATT Article III/XX Complex. 
What the SPS Agreement does is to somewhat reduce the incompleteness of the WTO contract by requiring that SPS measures be motivated by ('aim at') reducing national product-specific consumption externalities. It is often stressed by economists that the WTO is an 'incomplete contract'. This implies that it does not (and cannot) specify what is permitted of governments in every state of the world. Instead, the WTO contains only a few specific, unambiguous disciplines (the most obvious being the tariff bindings). From an economic perspective, both the GATT III/XX Complex and the SPS 2.2/5.1/5.7 Complex can be regarded as responses to contractual incompleteness in the WTO treaty. ${ }^{76}$

Horn (2006) notes that a complete contract that specifies permissible policies in all possible states of the world is simply infeasible: the costs of writing and enforcing any such agreement are prohibitive, even assuming heroically that governments are able to specify ex ante all the regulatory needs that may arise in the future. ${ }^{77}$ Both the GATT III/XX Complex and the SPS 2.2/5.1/5.7 Complex can be regarded as components of a state-contingent contract, delegating to the disputesettlement process the task of determining the state. But these provisions refer to a state that is described by virtue of conditions such as like products, less favorable treatment, lack of scientific basis, etc. The implication is that the degree to which state contingencies result in beneficial internalization of externalities (i.e. in contract completeness) needs to be examined.

Horn develops a model in which for given tariff commitments, a marginally binding national-treatment provision will increase government welfare, but moving beyond this and further tightening national treatment may reduce welfare. The problem caused by tariff bindings combined with a hypothesized strict national-treatment rule (one that is unable to use regulatory categories to distinguish between products) is that insofar as imported products cause externalities, governments no longer can use the tariff to offset these. Instead they must use domestic instruments, which, because of national treatment, must apply equally to local and imported goods. As a result, an importing country that is being forced to abide by an equal-taxation dictum will set a uniform tax that is, from an international efficiency point of view, too high with regard to the domestic product, and too low with regard to the imported product. As a consequence, provided the externality problem is sufficiently severe, the imposition of national treatment may be internationally inefficient. ${ }^{78}$ Horn explains that information about government

76 See, e.g., Henrik Horn, Giovanni Maggi, and Robert Staiger (2008), 'Trade Agreements as Endogenously Incomplete Contracts', mimeo, forthcoming in the American Economic Review, 2009.

77 Henrik Horn (2006), 'National Treatment in the GATT', 96:1 American Economic Review 394.

78 Costinot develops a model showing that national treatment results in standards that are excessively restrictive, due to failure to take account of the interests of foreign producers exporting to the regulating market. On the other hand, under a regime of mutual recognition in which each state undertakes to accept as satisfactory the regulation of the home state of the exported good, standards will be too low due to a race-to-the-bottom effect in which the regulating government fails to account for foreign externalities. See Arnaud Costinot (2008), 'A Comparative Institutional Analysis of Agreements on Product Standards', 75 Journal of International Economic Law 197. 
preferences is at the core of the problem that national treatment is intended to solve:

If we were to assume that such information [regarding government preferences in order to determine the first-best solution] is verifiable, in the context of the present model there would exist an even simpler solution than the market access rule: a provision simply requesting the parties to 'set internal taxes to their firstbest levels.' This would implement the first-best outcome even if tariff negotiators were myopic, as long as the tariffs were set sufficiently low, since this would leave room to set total taxes at the first-best level, once the state of nature is realized. Presumably, the reason why we do not see such a provision lies in the difficulty to prove whether a set of taxes that benefits domestic interests, and harms foreign interests, is chosen to exploit neighbors, or because the importing government's preferences are such as to make the chosen taxes efficient from a global point of view. That is, it requires the adjudicator to effectively determine the intent behind the de facto discriminatory taxes, something the Appellate Body in the WTO has repeatedly (but not always very convincingly) claimed to be irrelevant to its decisions. ${ }^{79}$

The question raised by Horn is precisely the one discussed above regarding the ability to determine whether domestic regulators are engaging in first-best regulation, or protectionism. The scientific-basis requirement imposed by the SPS 2.2/ 5.1/5.7 Complex may be said to respond to precisely this question: how do we determine the intent behind de facto discrimination - how do we get closer to a requirement to set internal regulation at its first-best level? While there is no WTO law requirement that domestic regulators set internal regulations to their first-best levels, the scientific-basis requirement achieves a closer approximation of this test than mere national treatment. In order to get closer to a first-best level, it might be necessary to discipline 'appropriate level of protection'.

The nature of the externality arising from imports is left unclear in the Horn analysis, which is very general. In the case of SPS, tariffs would often be very poor substitutes for regulation - tariffs cannot address the local consumption externality or information problem that is created by or associated with the characteristics of the product or its by-products. If the imported products cause negative externality problems because they are different from domestic products, the imported products may well not be 'like' the domestic products, and so Article III would not require 'no less favorable' treatment. To revert to the case of hormones, if products with and without hormone residues are sufficiently different, the GATT Article III/XX Complex may not provide disciplines to preclude the protectionist use of product regulation.

Substantively, the SPS disciplines requiring there to be a scientific basis for SPS measures are closely related to the GATT non-discrimination doctrine, in that they define the necessary (but not sufficient) conditions for concluding that specific SPS

79 Horn, supra note 78 , at 402 . 
measures cannot be justified. The SPS Agreement goes beyond the GATT Article III/XX Complex by imposing requirements on governments regarding the criteria that must be satisfied as a precondition for imposing a specific SPS measure, while leaving the level of the measure to the discretion of the government. The constraint is a weak one, in that a minimum threshold criterion applies: there must be a scientific basis for the measure, even if the scientific evidence represents divergent or minority views in the profession. The de facto protection (market segmentation) created by an SPS measure must be motivated by demonstrating that the measure is addressing a market failure (consumption externality), as reflected in the existence of some scientific basis for a health or safety concern.

The scientific-basis requirement is a means for determining the intent of an SPS measure, a factor that is ostensibly not relevant in GATT national-treatment cases. But scientific justification is not a move away from a concern with preventing illegitimate discrimination against imported products. Instead this element of postdiscrimination regulation in the WTO is the test that is used to determine whether there is de facto discrimination and a protectionist effect created by an SPS measure. Although the 'scientific basis' test can therefore be regarded as a proxy measure of intent needed to justify an SPS measure, the AB report in Continued Suspension makes clear it is a weak test: governments are free to apply whatever level of protection they deem appropriate, a minority scientific view is enough to justify a measure, and panels have no business assessing what is 'good science', evaluating whether the risk assessment undertaken by a government is 'correct', or giving more weight to the majority view in the scientific community.

Insofar as the specific SPS measures that are adopted by governments are targeted at market failures that have effects on national objectives/territory, any international negative spillovers associated with the SPS norms that are adopted will reflect the national preferences and attitudes towards risk and the fact that such preferences and attitudes will differ across countries. Given the unwillingness of WTO Members to accept strong disciplines regarding harmonization or acceptance of minimum standards in this area, the outcome of the Continued Suspension case seems to represent an appropriate application of the SPS Agreement. The SPS Agreement makes a marginal additional contribution in further completing the WTO 'contract' compared to the potential outcome of litigation of such cases under GATT alone. That said, there is extensive economic literature concluding that from a cost-benefit perspective the levels at which SPS measures are set is often excessive, imposing high costs with very little to show in terms of greater safety or health. ${ }^{80}$ Ultimately, improving the cost-benefit ratio of product regulation requires economic analysis and public-policy debate informed by assessments of actual risks and the impacts of specific measures.

80 See Bernard Hoekman and Michel Kostecki (2009), The Political Economy of the World Trading System, Oxford University Press, for a brief review of some of this literature. 